\title{
The effect of educational background on entrepreneurial intention
}

\author{
Hau Doan Xuana, Thanh Le Trung ${ }^{a}$, Huyen Nguyen Ngọca, Linh Nguyen Thi Phuonga ${ }^{a}$, Doanh \\ Duong Cong ${ }^{a^{*}}$ and Trang Nguyen Quynh ${ }^{b}$
}

\author{
${ }^{a}$ National Economics University, Vietnam \\ ${ }^{b}$ Banking Academy, Vietnam \\ CH R O N I C L E

\begin{tabular}{l} 
Article history: \\
Received: July 72019 \\
Received in revised format: July 7 \\
2019 \\
Accepted: August 10, 2019 \\
Available online: \\
August 10, 2019 \\
\hline Keywords: \\
Educational background \\
Perceived opportunities \\
Perceived capacities \\
Entrepreneurial intention
\end{tabular}

\section{Introduction}

Entrepreneurship is becoming a worldwide phenomenon for its positive contribution to economic development across the globe. Guerrero et al. (2008) state that entrepreneurship is seen as an innovative and creative process, which plays the potential role in creating added and new value to products/services, increasing productivity, creating new job opportunities, revitalizing and diversifying markets, improving social welfare, and developing the national economy. Historically, the establishment of new market, the relationship with profit orientation and capital investment (Schumpeter, 1975) led to the beliefs of economics regarding to the responsibility of entrepreneurship for economic growth (Cole, 1965; Weber, 1930). Since "Đổi Mới” (Renovation process) in 1986, The Vietnamese economy has transformed from planned to market-oriented economy. By pursuing the new policies, Vietnam Government encouraged internal restructuring. According to the Doing Business 2017 Report of the World Bank, Vietnam ranks $60^{\text {th }}$ among 138 countries in the Global Competitive Report 2017. Vietnam attracted more foreign direct

\footnotetext{
* Corresponding author.

E-mail address: doanhdoanh.qtkd.neu@gmail.com (D. Duong Cong)

(C) 2020 by the authors; licensee Growing Science, Canada doi: $10.5267 /$ j.msl.2019.8.013 
investment (FDI) than China in 2016 and surpassed Malaysia and Thailand in the Greenfield FDI Performance Index, leading in the region (Doing Business in Vietnam, 2017). In addition, in 2007, FDI in Vietnam reached the highest number over the 10-year period, amounting to USD 35 billion. By the end of November 2017, the figure for FDI projects reached 24,580 registrations, accounting for USD 317 billion. While around $60 \%$ of the funds were allocated to the processing and manufacturing industries, $16.6 \%$ of FDI projects poured into real estate and only $6.6 \%$ was spent on the utility supply sector. In fact, South Korea is still seen as the top investing nation with the registered capital of USD 57.5 billion, accounting for $29 \%$ of more than 100 nations and territories, followed by Japan (11\%) and Singapore $(10 \%)$. The population of Vietnam is over 92 million people, with the median age of 30, ranked as the $14^{\text {th }}$ most populous nation in the world. As a result, Vietnam attracts many investors because of its potential customers and employees. In terms of gross domestic product (GDP) growth, GDP in 2015 was $6.7 \%$, however, it dropped to only $6.2 \%$ in 2016 before an impressive recovery in 2017, when it reached $6.8 \%$. Consequently, Vietnam's GDP growth has averaged approximately $7 \%$ over the last 20 years. Consequently, the recognition of the role of entrepreneurship is growing among government, society and researchers as well. According to the General Statistics Office (GSO, 2017), there are 561,064 active enterprises in Vietnam (11.1\%) in comparison with previous year. 126,859 new enterprises were established in 2017, increased by $15 \%$ - the highest level of enterprises established, the average capital of each firm is estimated at 448,800 USD. Also, according to General Statistics Office (GSO, 2018), the number of newly-established enterprises in the first four months of 2018 up reached to approximately 41,300, increasing $4.3 \%$ year-on year while the registered capital reached at 412 trillion VND, rising $12 \%$. Keeping pace with the high rate of economic growth of Vietnam, private sectors increased significantly and contributed nearly $40 \%$ to GDP and the private firms is projected to contribute $50 \%$ to GDP by 2020 . Even though the concept of entrepreneurship has become more universal in the world, almost all entrepreneurial intention studies conducted in Western countries, in which the entrepreneurial ecosystem and the market economy have been developed. There is a lack of studies of entrepreneurship carried out in transitional economies such as Vietnam, especially in examining the effect of educational background on entrepreneurial intention among youths. As a result, this research gap should be fulfilled. The fundamental objective of this study is to investigate the impact of educational background in perceived opportunities, perceived capacities, and entrepreneurial intention. This study also provides a useful sightseeing of youths' entrepreneurship to policy makers, education managements and governments with the goal of fostering students' entrepreneurship, developing entrepreneurial ecosystem and enhancing business environment. In addition, authors also hope that this study will bring an interesting insight to researchers and academic staffs.

This study is organized in the following manner: Firstly, theoretical background involving entrepreneurship, entrepreneurial intention, perceived opportunities, perceived capacities and hypothesizes will be represented. Second, research method, research framework and method of collecting data as well will be described. Third, authors will discuss the research results. Finally, conclusion and recommendation for further will be presented.

\section{Literature review}

\subsection{Entrepreneur and entrepreneurship}

Entrepreneurship is connected to economic activities (Kot et al., 2016, p. 208). In fact, many governments and scientists take consideration into the development of SMEs, which are perceived as the sustainable path to develop national economies (Sivvam, 2012, p.13; Ambrish, 2014, p.225). Grzybowska (2004) defined entrepreneurship as a conscious action of individuals, that depends on many conditions such as economic activities, technologies, culture, policy and social and political problems as well. However, willingness to take risk plays the important part to achieve successes in business. Thus, entrepreneurs are responsible to act in a manner that paves the ways for economic activities and generating wealth by increasing income, developing skills and creating jobs (Gaweł, 2010, p. 60). However, entrepreneurship research is still seen as the developing field within the area of a management science that is especially 
visible when the studies of entrepreneurship are based on comparison with disciplines from which it appeared obviously. Moreover, its own method and theories are also needed to develop (Kot et al., 2016, p. 208; Bygrave, 1989, p. 8). There are many definitions for entrepreneurship developed over the few recent decades. Schumpeter (1975) considered that entrepreneurs are people who create new products or services in new or existing market and entrepreneurship becomes one of the most important factors in countries' economic growth (De Bruin et al., 2006, p. 686). "The environment itself creates entrepreneurship" (Bernat et al., 2016, p. 271), the reason is that operating organizations must be performed for not only reacting quickly to unanticipated changes, but also "to adapt to unpredicted outcomes of the predicted changes" (Timmons, 1990). Kirzner (1985) defined that entrepreneur is a person who might optimize information to discover the new and improved business opportunities (Korpysa, 2012). Talpas (2014, p.198) considered entrepreneurship as a process that can be recognized throughout business activities by showing effective leadership within uncertain market, risks and competitive conditions, while Zimmerer and Scarborough (1996, p.19) claimed that entrepreneurs can also be known as owners who, with skillful manner, are able to associate various factors of production, transforming a smaller economic resources into a bigger platform effectively and rising profits. Also, entrepreneurship is the process of creating and building new venture and new business organization (Shane, \& Venkataraman, 2000), that not only provides goods and services, creates job opportunities but also contributes to the development of economy and the national income. Linda et al. (2017) argued that "it is the process of designing, launching and running a new business", and it also tends to do some topics such as policy, government programs, entrepreneurial training, funds, etc. that not only promotes the development of starting a new business but it also supports entrepreneurs in the business activities. In addition, OECD (2006) stresses that entrepreneurship is defined as a process, which entrepreneurs establish and develop enterprises to supply new products and services, or create additional value to products and services. From this definition, Adekiya and Ibrahim (2015) deduced that entrepreneurs are seen as enterprising individuals who are involved in an economic behavior with the desirability of setting up and creating value to meet human needs. Therefore, there are many definitions of entrepreneurship. However, in summary, character words, such as willingness to take risks, innovativeness, opportunism, new products, new processes, and creating a new business venture, are concluded in combined definitions (Bird \& Brush, 2002, p. 41). Generally, entrepreneurship is a new business creation by a person alone or cooperating with others.

\subsection{Entrepreneurial intention}

In terms of entrepreneurship research, Bygrave and Hofer (1991, p.15) state that "Good science has to begin with good definition". Individual entrepreneurial intention can be most appropriately and practically defined as the intention of a person to start up a new own business venture and intentionally plan to do some of the times in the future. However, this time can be imminent and indeterminate, or might never be achieved in the future (Thompson, 2009, p.676). Entrepreneurial intention refers to the intention to carry out entrepreneurial behavior. Bird and Jellinek (1998) described entrepreneurial intention as the level of cognitive awareness related to set up a new business. While Krueger and Brazeal (1994) has defined entrepreneurial intention as the intent to set up a new business, or the intent to be self-employed (Douglas \& Shepherd, 2002) or the intent to own a business (Crant, 1996). There are many reasons such as personal circumstances, social and politic issues and business environment, which might become either big obstacles or motivated factors to transform this intent becoming a reality. Thus, entrepreneurial intention is perceived as an essential and fundamental condition to be a nascent entrepreneur. Whereas entrepreneurship is determined as the emergent process of an organization (Gartner et al., 1992), an individual's intention to pursue an entrepreneurial career is crucial to this process (Lee et al., 2011, p.126). Moreover, entrepreneurial intention is considered the first step in a series of actions to build an organization (Bird, 1988), yet Fishbein and Ajzen (1975) argued that intentions toward a behavior can be seen as important indicators of that behavior. In other words, intentions are still seen as the best predictor of individual behavior (Krueger, 2008). According to Ajzen (1991), who introduced Theory of Planned Behavior, intentions are determined by social/subjective norms and perceived behavioral control. Social norms are considered individual's perception of his or her behavior that is consistent with significant 
thoughts of other, while perceived behavior control is the range of the target behavior within the ability of a decision maker (Esfandiar et al., 2017). Do and Dadvari (2016) also defined entrepreneurial intention as an attentive state of mind that reflects personal experience, awareness and interest toward planned entrepreneurial activity. Since the decision to be an entrepreneur is voluntary and conscious (Krueger et al., 2000). Entrepreneurship is necessary to succeed in the long-term and reflects the economic growth prospects of a country as well. Paul and Shrivatava (2016) have shown a comparative investigation of entrepreneurial intention, country culture and proactive behavior among young managers in India (developing country) and Japan (developed country) based on statistical analysis. This study indicated that the entrepreneurial intentions of young managers from developing countries was not always stronger than that of those from developed countries although on behalf of the entrepreneurial level, developing countries such as India often stand behind developed countries, like Japan. Consequently, it is essential to develop entrepreneurial skills and cultures in developing countries.

\subsection{Perceived capacities}

Perceived capacities is defined as the mostly researched and acknowledged antecedent of entrepreneurial intention (Ebrahim \& Schott, 2011), known as self-efficacy. Self-efficacy is simply seen as an individual's belief in his or her own abilities and skills, which is the key indicator of perceived feasibility of business creation as it drives an optimistic self-sightseeing in the pursuit of objectives (Esfandiar et al., 2017, Barbosa et al., 2007). Perceived capacities also can be described as the proportion that individuals' believes that they possess the capacities to achieve certain goals, especially in relation to entrepreneurship (Lin et al., 2017). In addition, Prodan and Drnovsek (2010) reported that self-efficacy is the most influential predictor in elucidating academics' entrepreneurial intention, compared with other factors. Entrepreneurship is also related to possessing subjective visions about business opportunities and assembling resources and capacities to transform entrepreneurial intention into business reality (Shepherd \& DeTienne, 2005). There are various types of capacities while dynamic capacities of integrating, building, and reconfiguring internal and external factors to address quickly changing environment are determined as one of the most important factor (Teece et al., 1997). Shepherd and Krueger (2002) believe that high self-efficacy, either at individual or group level, results in high perceived feasibility of entrepreneurial actions. However, the importance of perceived capacities in determining entrepreneurial intention has been broadly discussed, yet there is a scarcity of studies exploring the effects of educational background on perceived capacities and entrepreneurial intention even in developed countries. Thus, there is a necessity in the context of transitional economy in Vietnam to investigate the relationship between education background and perceived capacities as well as entrepreneurial intention.

H1: Perceived capacities are positively affected by educational level.

H2: Perceived capacities are positively affected by field of study.

$\mathbf{H}_{3}$ : Entrepreneurial intention is positively affected by educational level.

H4: Entrepreneurial intention is positively affected by field of study.

H5: Entrepreneurial intention is positively affected by perceived capacities.

\subsection{Perceived opportunities}

Perceived opportunities reflect the recognition of entrepreneurial opportunities (Wasdani \& Mathew, 2014). Stevenson and Jarillo (1990) considered entrepreneurship as the pursuit of opportunities, which is conditioned on desirability and feasibility. Perceived opportunities vary among each individual since his or her desires and abilities are different from others. In addition, perceived opportunities also refer to the percentage of the people who believe there is an occasion to set up a business in the next six months in their immediate conditions (Lin et al., 2017). Shapero and Sokol (1982) stress that entrepreneurial process requires an awareness of how credible opportunities are. The intention of starting a new venture can automatically involve in the perception of business opportunities and the determination of these business opportunities is perceived as the important and essential skills that potential entrepreneurs must possess (Vidal-Sune, 2013). Lin et al. (2017) argue that entrepreneurs who pursue an opportunities and 
put efforts to increase their income and independence nowadays tend to be younger while the determination of business opportunities and the start-up process can be facilitated by governments through many programs such as subsides and financial fund, training programs, advices, etc. (Dahles, 2005; Keushnigg \& Nielsen, 2004; Lorenzo et al., 2008). In this study, the influence of educational background on perceived opportunities and entrepreneurial intention in the transitional economy context of Vietnam will be considered.

H6. There is a positive relationship between educational level and perceived opportunities.

$\mathbf{H}_{7}$. There is a positive relationship between field of study and perceived opportunities.

H8. There is a positive relationship between perceived opportunities and entrepreneurial intention.

H9. There is a positive relationship between perceived opportunities and perceived capacities.

\section{Methodology}

This study mainly focuses on investigating the effect of educational background on perceived opportunities, perceived capacities and entrepreneurial intention among Vietnamese students. In terms of research techniques, quantitative method such as certain descriptive statistics, explore factor analysis (EFA), KMO and Bartlett test, correlation coefficient analysis, and multiple regression throughout SPSS 20.0 are used to show the relationship between educational background (educational level \& field of study) and perceived opportunities, perceive capacities, entrepreneurial intention. Moreover, the ChiSquare and Cramer's V Tests are also employed to indicate the educational background difference in entrepreneurial intention. Even though more than 1000 questionnaires were distributed among students at universities, colleges and institutes in Vietnam, only 617 students $(N=617)$ fulfilled completely. The surveys are divided into 2 sections, which are based on the objective of the study, theoretical background and hypothesizes. In the first section, demographic questions are designed to obtain respondents' information such as gender, age group, year of study, educational level, field of studies and the willingness level to take risks. In the second section, the questions are designed to allow respondents' providing their viewpoint regarding of perceived opportunities, perceived capacities and entrepreneurial intention, which are based on the previous studies (Bagozzi et al., 2003; Krueger, 2009; Adekiya \& Ibrahim, 2016; Lin $\underline{\text { et al., }}$ $2017)$ and followed the six-point Liker scale ( $1=$ Strongly disagree, $2=$ Disagree, $3=$ Slightly disagree, 4= Slightly agree, 5= Agree, $6=$ Strongly agree $)$.

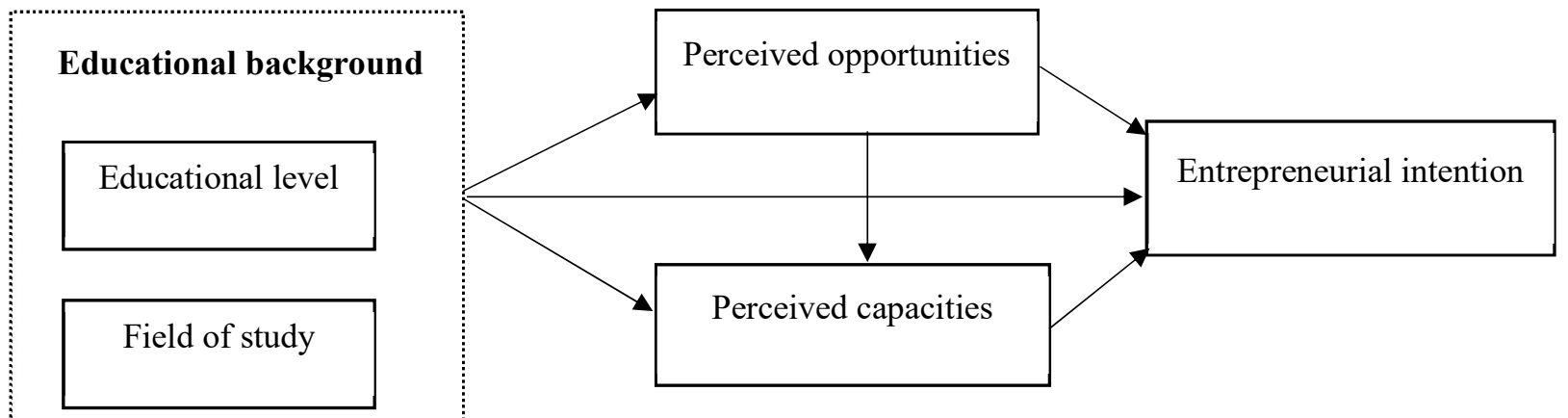

Fig. 1. Research framework

\section{Results}

\subsection{Demographic profile}

Demographic information of respondents is presented in Table 1. The results of descriptive statistics of demographic layouts illustrate that approximately $2 / 3$ respondents are female $(39.5 \%$ for men and $60.7 \%$ for women). Moreover, the main proportion of respondents aged from 20-24 years old (81.5\%), compared with only $12.5 \%$ and $6.0 \%$ respondents aged from $18-19$ years old and over 24 years old, respectively. Noticeably, the figure for student who are associated with economics field makes up $67.9 \%$, which is twofold higher than that for non-economics students (just 32.1\%). In addition, the high percentage of 
respondents are university and college students, which account for $76.5 \%$, followed by master students $(18.4 \%)$ and high school students $(5.0 \%)$. Finally, nearly a half of respondents are the third-year students, while $32 \%, 15.6 \%, 10.7 \%$ of them are the first-year, second-year and final-year students, respectively.

\section{Table 1}

Demographic information of respondents

\begin{tabular}{|c|c|c|c|c|c|}
\hline \multicolumn{2}{|l|}{ Variables } & \multirow{2}{*}{$\begin{array}{l}\text { Frequency } \\
243\end{array}$} & \multirow{2}{*}{\begin{tabular}{|l|}
$\mathbf{\%}$ \\
39.3
\end{tabular}} & \multirow{2}{*}{$\begin{array}{l}\text { Mean } \\
1.6068\end{array}$} & \multirow{2}{*}{$\begin{array}{l}\text { Std. Deviation } \\
0.48886\end{array}$} \\
\hline Gender & Male & & & & \\
\hline & Female & 374 & 60.7 & & \\
\hline \multirow[t]{3}{*}{ Age } & $18-19$ & 77 & 12.5 & \multirow[t]{3}{*}{1.9352} & \multirow[t]{3}{*}{0.42527} \\
\hline & $20-24$ & 503 & 81.5 & & \\
\hline & $>24$ & 37 & 6.0 & & \\
\hline \multirow[t]{3}{*}{ Education (EL) } & High School & 31 & 5.0 & \multirow[t]{3}{*}{1.1459} & \multirow[t]{3}{*}{0.49817} \\
\hline & University/College & 472 & 76.5 & & \\
\hline & Master & 114 & 18.4 & & \\
\hline \multirow{2}{*}{$\begin{array}{l}\text { Fields of studies } \\
\text { (FS) }\end{array}$} & Economics & 419 & 67.9 & \multirow[t]{2}{*}{1.3209} & \multirow[t]{2}{*}{0.46720} \\
\hline & Non-economics & 198 & 32.1 & & \\
\hline \multirow[t]{4}{*}{ Year of studies } & First year & 198 & 32.0 & \multirow[t]{4}{*}{2.3117} & \multirow[t]{4}{*}{1.03449} \\
\hline & Second year & 96 & 15.6 & & \\
\hline & Third year & 257 & 41.7 & & \\
\hline & Final year & 66 & 10.7 & & \\
\hline
\end{tabular}

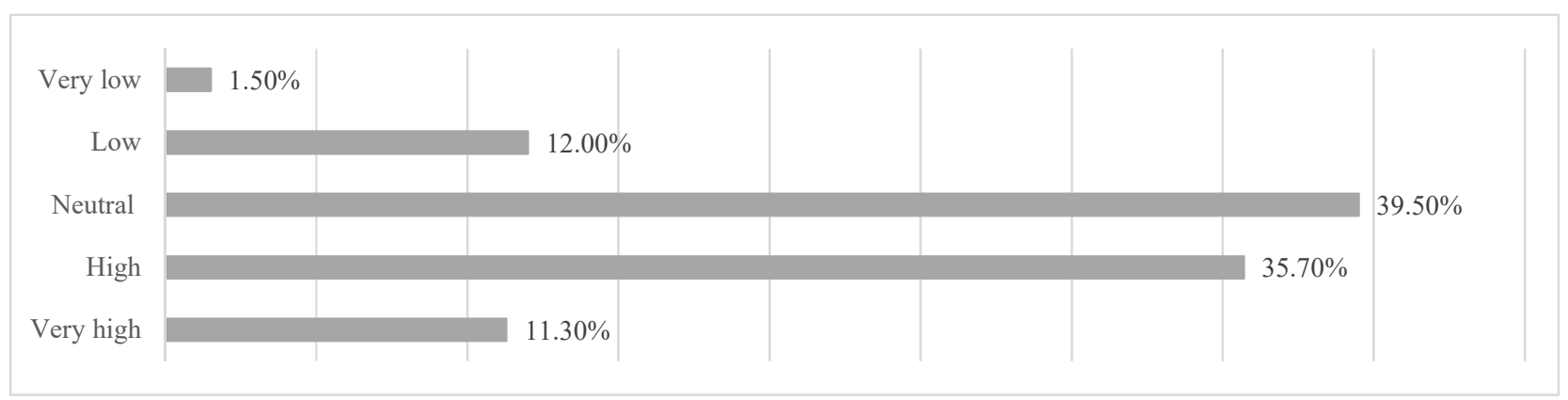

Note: $\mathrm{N}=617,1=$ very low, $2=$ low, $3=$ neutral, $4=$ high and $5=$ very high

Fig 2. Respondents' willingness level to take the risks

Authors also evaluated the willingness level for taking risks among Vietnamese students, which is described in Fig. 2. Overall, 47\% of the students believe that their willingness level to take risks are high and very high (35.7\% at high level, and $11.3 \%$ at very high). However, a considerable percentage of respondents argues that their willingness level to take risks are neutral $(39.5 \%)$ and $13.5 \%$ at low and very low level.

\subsection{Reliability and explorative factor analysis for variables}

Table 2 reports that the values of Cronbach's Alpha for variables such as EI, PO and PC reach at 0.601, 0.664 and 0.735 . There are rather high values, indicating good reliability. The results of KMO and Bartlett's Test for independent and dependent variables are presented in Table 3. KMO and Bartlett's Test provide reports on important tests that the data is suitable for Factor Analysis and KMO provides a measure of whether the distributions of values in the variables is suitable. The value for independent variable is 0.766 , which is bordering on "middling" and the value for dependent variable is 0.674 (mediocre). Technically, as the size of sample making up 617, thus, the factor loading of EFA in this study is 0.30 . The significance value of both independent and dependent variables is 0.000 which is excellent. 
Table 2

Reliability test and descriptive statistics for variables

\begin{tabular}{|c|c|c|c|}
\hline Variables, items & Mean & Std. Deviation & Cronbach's Alpha \\
\hline Entrepreneurial intention (EI) (Krueger, 2009; Adekiya \& Ibrahim, 2016) & & & \multirow[t]{6}{*}{0.641} \\
\hline EI1. I am determined to create my own business in the future. & 3.0666 & 1.39469 & \\
\hline EI2. I have very seriously thought of starting a firm. & 3.6721 & 1.16015 & \\
\hline EI3. My professional goal is to become an entrepreneur. & 2.2492 & 1.45564 & \\
\hline EI4. I am ready to make any form of sacrifice to become an entrepreneur. & 3.8911 & 1.10794 & \\
\hline EI5. If I had the opportunity and resources, I'd like to start a firm & 3.6808 & 1.24058 & \\
\hline Perceived opportunities (PO) (Lin et al., 2017) & & & \multirow[t]{5}{*}{0.664} \\
\hline PO1. I can identify business opportunities & 3.5422 & 1.15252 & \\
\hline PO2. There are plenty of good opportunities for the creation of new firms & 3.0942 & 1.24844 & \\
\hline PO3. I can easily pursue entrepreneurial opportunities & 3.2992 & 1.17448 & \\
\hline PO4. I can react quickly to good opportunities for a new business & 3.4813 & 1.21844 & \\
\hline Perceived capacities (PC) (Lin et al., 2017) & & & \multirow[t]{6}{*}{0.735} \\
\hline PC1. I have the knowledge required to start a new business & 2.6878 & 1.36520 & \\
\hline PC2. I have the skills required to start a new business & 3.6520 & 1.17350 & \\
\hline PC3. I have the experience required to start a new business & 2.5089 & 1.54187 & \\
\hline PC4. In my country, many people know how to start and manage a small business & 3.2199 & 1.27935 & \\
\hline PC5. In my country, many people have experience in starting new businesses & 3.7187 & 1.13311 & \\
\hline
\end{tabular}

Table 3

KMO and Bartlett's Test

\begin{tabular}{llll}
\hline Type of variables & & Independent & Dependent \\
\hline \multicolumn{2}{l}{ Kaiser-Meyer-Olkin Measure of Sampling Adequacy. } & 0.766 & 0.674 \\
\hline \multirow{3}{*}{ Bartlett's Test of Sphericity } & Approx. Chi-Square & 1455.719 & 434.427 \\
& $\mathrm{df}$ & 55 & 10 \\
& Sig. & 0.000 & 0.000 \\
\hline
\end{tabular}

\subsection{Correlation coefficients between variables}

Table 5 presents the correlation coefficients between variables such as educational level (EL), field of study (FS), perceived opportunities (PO), perceived capacities (PC) and entrepreneurial intention (EI). In terms of research framework, the model focuses on examining the effect of educational background, which includes educational level and field of study, on perceived opportunities, perceived capacities and entrepreneurial intention.

\section{Table 5}

Correlation coefficients between variables

\begin{tabular}{|c|c|c|c|c|c|c|}
\hline & & EI & PO & PC & EL & FS \\
\hline \multirow[t]{2}{*}{ EI } & Pearson Correlation & 1 & & & & \\
\hline & Sig. (2-tailed) & & & & & \\
\hline \multirow[t]{2}{*}{ PO } & Pearson Correlation & $0.704 * *$ & 1 & & & \\
\hline & Sig. (2-tailed) & 0.000 & & & & \\
\hline \multirow[t]{2}{*}{ PC } & Pearson Correlation & $0.619^{* *}$ & $0.461^{* *}$ & 1 & & \\
\hline & Sig. (2-tailed) & 0.000 & 0.000 & & & \\
\hline \multirow[t]{2}{*}{ EL } & Pearson Correlation & $0.128^{* *}$ & 0.057 & $0.195 * *$ & 1 & \\
\hline & Sig. (2-tailed) & 0.001 & 0.160 & 0.000 & & \\
\hline \multirow[t]{2}{*}{ FS } & Pearson Correlation & -0.031 & $-0.138 * *$ & -0.006 & 0.070 & 1 \\
\hline & Sig. (2-tailed) & 0.439 & 0.001 & 0.878 & 0.081 & \\
\hline
\end{tabular}

Note: $\mathrm{N}=617 ; * \mathrm{p}<0.05, * *: \mathrm{p}, 0.01$ (2-tailed).

The result indicates that there was a negative relationship between field of studies on entrepreneurial intention $(r=-0.031$, $p$-value $=0.439)$, perceived opportunities $(r=-0.138$, $p$-value $=0.001)$ and perceived capacities $(r=-0.006, p$-value $=0.878)$. However, with the higher significance level, educational level affected positively on entrepreneurial intention $(r=0.128$, $p$-value $=0.001)$, perceived opportunities $(r=0.057, p$-value $=0.0160)$ and perceived capacities $(r=195, p$-value $=0.000)$. In addition, 
entrepreneurial intention has been positively strong influenced by perceived opportunities $(r=0.704, p$ value $=0.000)$ and perceived capacities $(r=0.619, p$-value $=0.000)$.

\subsection{Multiple Linear Regression}

Multiple regression is used to predict the value of entrepreneurial intention given the value of educational background, perceived opportunities, and perceived capacities.

Table 6

Model summary ${ }^{\mathrm{b}}$

\begin{tabular}{|c|c|c|c|c|c|}
\hline Model & $\mathrm{R}$ & R-Square & Adjusted R Square & Std. Error of the Estimate & Durbin-Watson \\
\hline 1 & $0.784^{\mathrm{a}}$ & 0.615 & 0.613 & 0.49556 & 1.960 \\
\hline
\end{tabular}

According to Table 6, the overall Pearson coefficient between educational background (EL \& FS), perceived opportunities (PO), perceived capacities (PC) and entrepreneurial intention (EI) is provided. The result shows that the multiple correlation is $0.784(\mathrm{R}=0.784)$ and so the Adjust $\mathrm{R}$ Square is 0.613 (Adjusted $\mathrm{R}^{2}=0.613$ ) which proves that nearly $62 \%$ of variation of entrepreneurial intention can be explained by the model comprised of four variables (educational level, field of study, perceived opportunities, perceived capacities).

\section{Table 7}

ANOVA $^{\mathrm{a}}$

\begin{tabular}{rllllll}
\hline Model & & Sum of Squares & df & Mean Square & F & Sig. \\
\hline \multirow{2}{*}{1} & Regression & 239.335 & 4 & 59.834 & 243.639 & $0.000^{\mathrm{b}}$ \\
\cline { 2 - 6 } & Residual & 149.560 & 609 & 0.246 & & \\
\cline { 2 - 6 } & Total & 388.895 & 613 & & & \\
\hline a. & Dependent Variable: EI & & & & \\
b. & Predictors: (Constant), PO, PC, EL, FS & & &
\end{tabular}

Table 7 (ANOVA) reports the significance of regression model. In this study, the Sig. associated with the F-Test is 0.000 which is highly significant and confirms that the model can explain a significant amount of variation in the entrepreneurial intention. Moreover, the Mean Square column also confirms that very much of the variance is explained by the Regression line than by the Residual (59.834 compared to 0.246 ). This reinforces the conclusion that the model is good.

\section{Table 8}

Coefficients $^{\mathrm{a}}$

\begin{tabular}{|c|c|c|c|c|c|c|}
\hline \multirow[t]{2}{*}{ Model } & & \multicolumn{2}{|c|}{ Unstandardized Coefficients } & \multirow{2}{*}{$\begin{array}{c}\text { Standardized Coefficients } \\
\text { Beta }\end{array}$} & \multirow[t]{2}{*}{$\mathrm{t}$} & \multirow[t]{2}{*}{ Sig } \\
\hline & & B & Std. Error & & & \\
\hline & (Constant) & 0.444 & 0.116 & & 3.8450 & 0.000 \\
\hline & $\mathrm{PO}$ & 0.515 & 0.027 & 0.548 & 19.128 & 0.000 \\
\hline & $\mathrm{PC}$ & 0.318 & 0.025 & 0.363 & 12.596 & 0.000 \\
\hline & EL & 0.036 & 0.041 & 0.022 & 0.8670 & 0.386 \\
\hline & FS & 0.071 & 0.043 & 0.042 & 1.6450 & 0.000 \\
\hline
\end{tabular}

a. Dependent Variable: EI

Table 8 (Coefficients) represents the coefficients for the regression equation, which is:

Entrepreneurial intention $=0.444+0.515 \times$ perceived opportunities $+0.318 \times$ perceived capacities $+0.071 \times$ field of study $+0.036 \times$ educational level.

Particularly, the Standardized Coefficients Beta reports us the contribution each variable makes to the model. In this study, perceived opportunities are the most important: a variation of $1 \%$ in perceived 
opportunities would lead to a change of $0.515 \%$ in entrepreneurial intention $\left(\beta_{1}=515, p=0.000\right)$. Similarly, perceived capacities have the second strongest effect on entrepreneurial intention $\left(\beta_{2}=-0.318\right.$, $p=0.0000)$, followed by field of study $\left(\beta_{3}=0.071, p=0.000\right)$, and educational level $\left(\beta_{3}=-0.318, p=0.386\right.$ $>0.005)$ respectively. Fig. 3 shows the results of the proposed study.

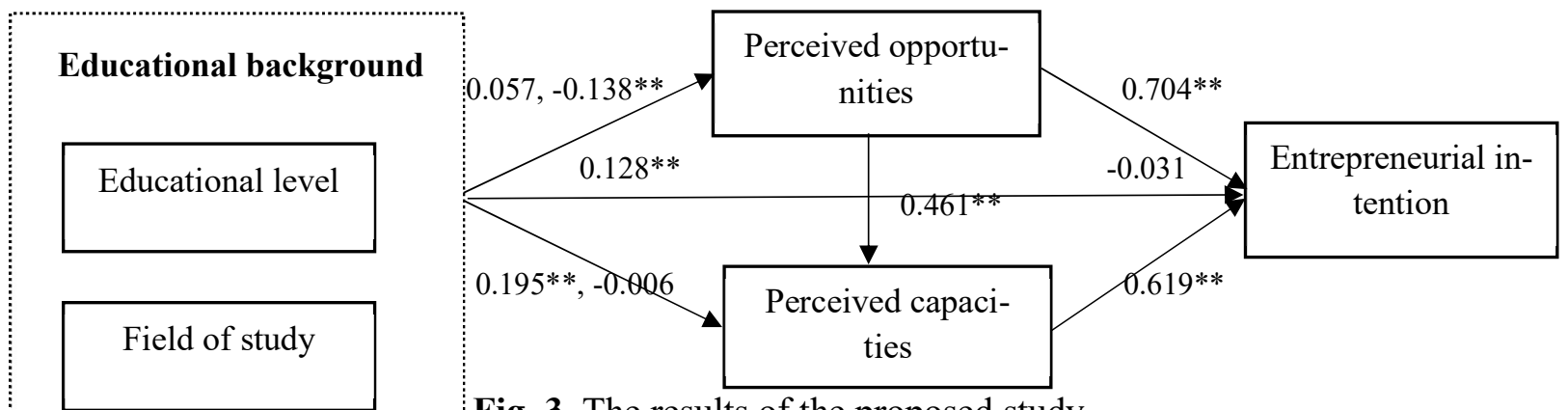

Fig. 3. The results of the proposed study

\subsection{Chi-Square and Cramer's V Tests for educational background difference in entrepreneurial inten- tion}

Chi-Square and Cramer's V Tests are employed to report the difference of educational background in entrepreneurial intention.

\section{Table 9}

Chi-Square and Cramer's V results for educational level difference in entrepreneurial intention

\begin{tabular}{|c|c|c|c|c|c|c|}
\hline \multirow[t]{2}{*}{ Chi-Square Tests } & \multicolumn{6}{|c|}{ Symmetric Measures } \\
\hline & Value & $\mathrm{df}$ & Asymp. Sig. (2-sided) & & Value & Approx. Sig. \\
\hline Pearson Chi-Square & $75.519^{\mathrm{a}}$ & 20 & 0.046 & Phi & 0.350 & 0.461 \\
\hline Likelihood Ratio & 76.271 & 20 & 0.013 & Cramer's V & 0.202 & 0.461 \\
\hline Linear-by-Linear Association & 10.055 & 1 & 0.110 & & & \\
\hline
\end{tabular}

The Chi-Square Tests in Table 9 shows that the probability of differences this larger or larger occurring by chance is 0.046 , which is smaller than the normal 0.05 criterion level used ( $95 \%$ significance). Thus, there are strong evidence of educational level difference in entrepreneurial intention. Moreover, Cramer's $\mathrm{V}$ change between 0 and 1, with 0 referring to no association and 1 shows the perfect association, the result in Table 9 indicates that the value is 0.350 , which means that the association between educational level and entrepreneurial intention makes up the moderate level.

\section{Table 10}

Chi-Square and Cramer's V results for field of study difference in entrepreneurial intention

\begin{tabular}{|c|c|c|c|c|c|c|}
\hline \multirow[t]{2}{*}{ Chi-Square Tests } & \multicolumn{6}{|c|}{ Symmetric Measures } \\
\hline & Value & $\mathrm{df}$ & Asymp. Sig. (2-sided) & & Value & Approx. Sig. \\
\hline Pearson Chi-Square & $26.678^{\mathrm{a}}$ & 25 & 0.372 & Phi & 0.208 & 0.372 \\
\hline Likelihood Ratio & 29.949 & 25 & 0.226 & Cramer's V & 0.208 & 0.372 \\
\hline Linear-by-Linear Association & 0.599 & 1 & 0.439 & & & \\
\hline
\end{tabular}

Analogously, Table 10 presents that there is no difference between fields of study in entrepreneurial intention $(p$-value $=0.372>0.05)$.

\subsection{Scatterplot for perceived opportunities, perceived capacities and entrepreneurial intention}

The scatterplot for perceived opportunities, perceived capacities and entrepreneurial intention is introduced in Fig. 3. 

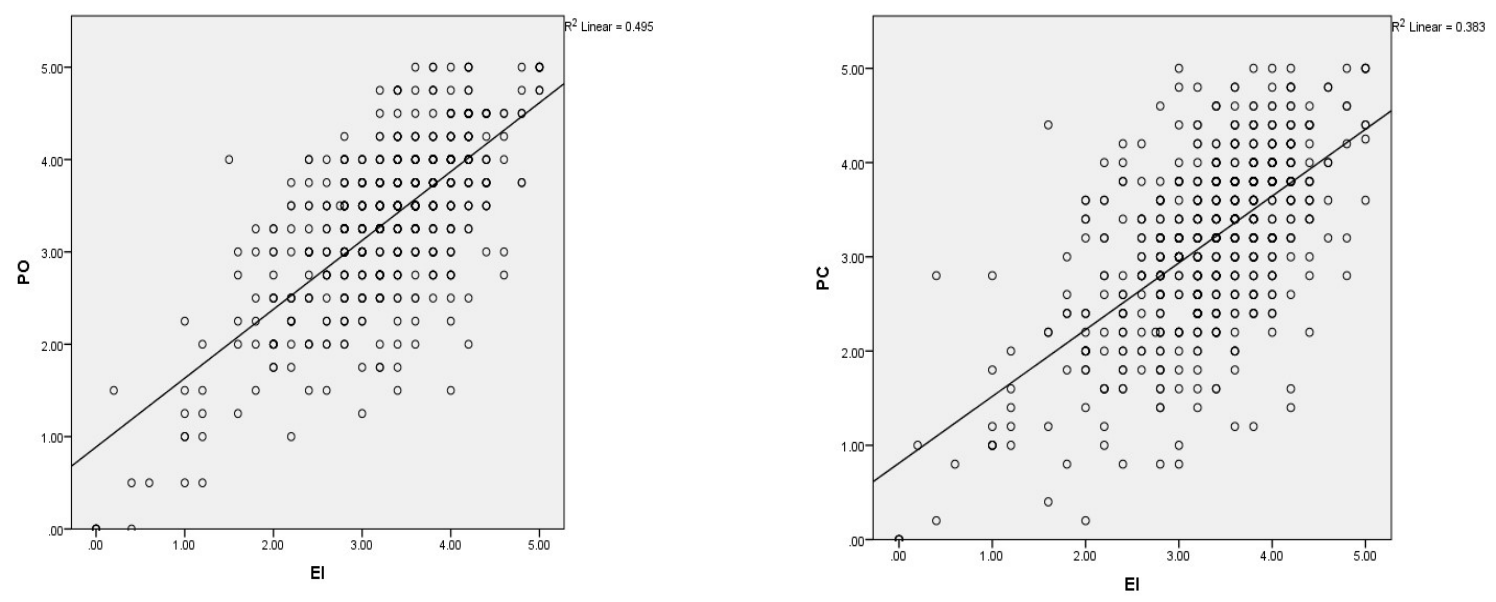

Fig. 3. Scatterplot for perceived opportunities (PO), perceived capacities (PC) and entrepreneurial intention $(\mathrm{EI})$

The values of the square of the Pearson correlation coefficient $\mathrm{R}$ are presented to the top right of the scatterplot. Specifically, the value of the square of the Pearson correlation R of PO, PC and EI reaches at 0.495 and $0.383\left(R^{2}\right.$ Linear $=0.495$ and 0.383$)$, thus, perceived opportunities and perceived capacities determined $49.5 \%$ and $38.3 \%$ the value of entrepreneurial intention.

\section{Conclusion}

The purpose of this study was to examine the impact of educational background (educational level \& field of study) on perceived opportunities, perceived capacities and entrepreneurial intention. During the research, it was recognized that there were not previous researches that covers the same topic being studied in the context of Vietnam.

During the tests, the hypotheses are accepted:

$\mathbf{H}_{1}$ : Perceived capacities are positively affected by educational level.

H3: Entrepreneurial intention is positively affected by educational level

Hs: Entrepreneurial intention is positively affected by perceived capacities

H6. There is a positive relationship between educational level and perceived opportunities.

H8. There is a positive relationship between perceived opportunities and entrepreneurial intention.

H9. There is a positive relationship between perceived opportunities and perceived capacities.

The following hypotheses are rejected:

H2: Perceived capacities are positively affected by field of study.

H4: Entrepreneurial intention is positively affected by field of study.

H7. There is a positive relationship between field of study and perceived opportunities.

In addition, the results of multiple linear regression analysis indicate that perceived opportunities are seen as the most influential factor on entrepreneurial intention, followed by perceived capacities, field of study and education level, respectively. Finally, the Chi-square and Cramer's V test elucidates that there was a strong evidence of educational level difference in entrepreneurial intention while no evidence to prove the difference of field of study in entrepreneurial intention. Even though this research provides a new and interesting insight to entrepreneurial filed, there are some limitations. First, authors only concentrated on investigating the direct effect of educational background on perceived capacities, perceived opportunities, and entrepreneurial intention, but further researches should be extend the research model by finding the indirect effects of variables on entrepreneurial intention or employing other variables such 
as entrepreneurial education programs, entrepreneurial training in order to figure out the relationship between education and entrepreneurial intention among youths. Secondly, small size and the availability sample collection can be considered as the other restriction of this study and further studies should use different approaches to obtain data in order to increase the significance level.

\section{References}

Adekiya, A. A., \& Ibrahim, F. (2016). Entrepreneurship intention among students. The antecedent role of culture and entrepreneurship training and development. The International Journal of Management Education, 14(2), 116-132.

Ambrish, D.R. (2014). Entrepreneurship development: An approach to economic empowerment of women, International Journal of Multidisciplinary Approach and Studies, 1(6), 224-232.

Ajzen, I. (1991). The theory of planned behavior. Organizational Behavior and Human Decision Processes, 50(2), $179-211$.

Bagozzi, R. P., Dholakia, U. M., \& Basuroy, S. (2003). How effortful decisions get enacted: The motivating role of decision processes, desires, and anticipated emotions. Journal of Behavioral Decision Making, 16(4), 273-295.

Barbosa, S. D., Gerhardt, M. W., \& Kickul, J. R. (2007). The role of cognitive style and risk preference on entrepreneurial self-efficacy and entrepreneurial intentions. Journal of Leadership and Organizational Studies, 13(4), 86-104.

Bernat, T., Maciejewska-Skrendo, A. \& Sawczuk, M. (2016). Entrepreneurship-risk-genes, experimental study. Part 1- entrepreneurship and risk relation. Journal of International Studies, 9(3), 207-278.

Bird, B., \& Jelinek, M. (1989). The operation of entrepreneurial intentions. Entrepreneurship Theory and Practice, 13(2), 21-30.

Bird, B., \& Brush, C. (2002). A gendered perspective on organizational creation. Entrepreneurship Theory and Practice, 26(3), 41-65.

Bygrave, C. \& Hofer, P.A. (1991). Theorizing about entrepreneurship. Entrepreneurship Theory and Practice, 16(2), 3-22.

Bygrave, W. D. (1989). The entrepreneurship paradigm (I): A philosophical look at its research methodologies, Entrepreneurship Theory and Practice, 14(1), 7-26.

Crant, J.M. (1996). The proactive personality scale as a predictor of entrepreneurial intentions. Journal of Small Business Management, 34(3), 42-49.

Cole, A.H. (1965). An approach to the study of entrepreneurship, in Aitken, H.G. (ed.), Explorations in enterprise. Harvard University Press.

De Bruin, A., Brush, C. G. \& Welter, F. (2006). Advancing a framework for coherent research on women's entrepreneurship. Entrepreneurship Theory and Practice. 16(1), 7-25.

Do, B. R., \& Dadvari, A. (2017). The influence of the dark triad on the relationship between entrepreneurial attitude orientation and entrepreneurial intention: A study among students in Taiwan University. Asia Pacific Management Review, 22(4), 185-191.

Doing Business in Vietnam (2017), A reference guide for entering the Vietnam market, https://www.pwc.com/vn/en/publications/2017/dbg-2017.pdf (10.02.2018).

Douglas, E. J., \& Shepherd, D. (1997). Why entrepreneurs create businesses: a utility maximizing response. Frontiers of Entrepreneurship Research, 17, 185-186.

Ebrahim, M. \& Schott, T. (2011). Entrepreneurial Intention Promoted by Perceived Capacities, Risk Propensity and Opportunities Awareness: A Global Study. Paper for conference of International Council for Small Business, Stockholm.

Esfandiar, K., Sharifi-Tehrani, M., Pratt, S., \& Altinay, L. (2019). Understanding entrepreneurial intentions: A developed integrated structural model approach. Journal of Business Research, 94, 172-182.

Fishbein, M.\& Ajzen, I. (1975) Belief, Attitude, Intention, and Behavior: An Introduction to Theory and Research. Addison-Wesley, New York.

Gartner, W. B., Bird, B. J., \& Starr, J. A. (1992). Acting as if: Differentiating entrepreneurial from organizational behavior. Entrepreneurship Theory and Practice, 16(3), 13-32.

Gaweł, A. (2010). The relationship between entrepreneurship and unemployment in the business cycle. Journal of International Studies, 3(1), 59-69.

Grzybowska, A. (2014). Przedsiębiorczość jako determinanta konkurencyjności przedsiębiorstw, Przedsiębiorczość i Zarzadzanie, 2, 19-28. 
GSO (2017). Social and Economic Situation in 2017, https://www.gso.gov.vn/default_en.aspx?tabid=622\&ItemID $=18670(20.02 .2018)$.

GSO (2008). Social and economic situation in 4 months of 2018. http://www.gso.gov.vn/default en.aspx?ta$\underline{\text { bid }=622 \& \text { ItemID }=18820}(26.05 .2018)$

Guerrero, M., Rialp, J., \& Urbano, D. (2008). The impact of desirability and feasibility on entrepreneurial intentions: A structural equation model. International Entrepreneurship and Management Journal, 4(1), 35-50.

Kot, S., Meyer, N., \& Broniszewska, A. (2006). A cross-country Comparison of the Characteristics of Polish and South Africa Women Entrepreneurs. Economics and Sociology, 9(4), 207-221.

Krueger, N. F. (2009). Entrepreneurial intentions are dead: Long live entrepreneurial intentions. In A. Carsrud, \& M. Brännback (Eds.). Understanding the entrepreneurial mind: Opening the black box. New York: Springer, 51-72.

Krueger, N. F., \& Brazeal, D. V. (1994). Entrepreneurial potential and potential entrepreneurs. Entrepreneurship: Theory and Practice, 18(1), 91-105.

Krueger, N. (2008). Entrepreneurial Resilience: Real and Perceived Barriers to Implementing Entrepreneurial Intentions. Working Paper, SSRN, http://papers.ssrn.com/sol3/papers.cfm?abstract $\mathrm{id}=1155269$ (11.04.2018).

Krueger, N. F., Reilly, M. D., \& Carsrud, A. L. (2000). Competing models of entrepreneurial intentions. Journal of Business Venturing, 15(5), 411-432.

Kirzner, I. (1985). Discovery and the capitalist process. Chicago: University of Chicago Press.

Lee, L., Wong, P. K., Foo, M. D. \& Leung, A. (2011). Entrepreneurial intentions: The influence of organization and individual factors. Journal of Business Venturing, 26, 124-136.

Linda, L.L., Ana, V.P., \& Cheng-Nam, C. (2017). Factors related to the intention of starting a new business in EL Salvador. Asia Pacific Management Review, 22, 212-222.

OECD. (2006). Entrepreneurship and local economic development. USA: OECD LEED Publishers.

Paul, J. \& Shrivatava, A. (2016). Do young managers in a developing country have stronger entrepreneurial intentions? Theory and debate. International Business Review, 25, 1197-1210.

Prodan, I., \& Drnovsek, M. (2010). Conceptualizing academic-entrepreneurial intentions: An empirical test. Technovation, 30(5-6), 332-347.

Shane, S. \& Venkataraman. S. (2000). The promise of entrepreneurship as a field of research. Academy of Management Review, 25(1), 217-226.

Schumpeter, J.A. (1975). Capitalism, socialism and democracy. $3^{\text {rd }}$ ed., New York.

Shepherd, D. A., \& DeTienne, D. R. (2005). The impact of prior knowledge and financial reward on the identification of opportunities. Entrepreneurship Theory and Practice, 29(1), 91-112.

Shepherd, D. A., \& Krueger, N. F. (2002). An intentions-based model of entrepreneurial teams' social cognition. Entrepreneurship Theory and Practice, 27(2), 167-185.

Sivvam, M. (2012). Women entrepreneurship: An Indian perspectives. Saarbrücken, Germany: LAP Lambert.

Talpas, P. (2014). Integration of Romani women on the labor market. Polish Journal of Management Studies, 10(1), 198-203.

Teece, D. J., Pisano, G., \& Shuen, A. (1997). Dynamic capabilities and strategic management. Strategic Management Journal, 18(7), 509-533.

Thompson, E. R. (2009). Individual entrepreneurial intent: Construct clarification and development of an internationally reliable metric. Entrepreneurship Theory and Practice, 33(3), 669-694.

Timmons, J.A. (1990). New Venture Creation: Entrepreneurship for the $21^{s t}$ Century, Irwin/McGraw-Hill, Boston.

Wasdani, K. P., \& Mathew, M. (2014). Potential for opportunity recognition along the stages of entrepreneurship. Journal of Global Entrepreneurship Research, 4(1), 7.

Weber, M. (1978). Economy and Society. University of California Press, Berkeley, CA.

Zimmerer, T. \& Scarborough, N. M. (1996). Entrepreneurship and new venture formation. New Jersey: Prentice Hall.

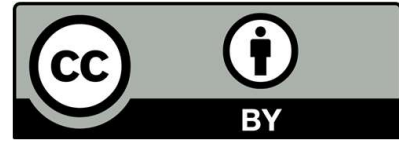

(C) 2020 by the authors; licensee Growing Science, Canada. This is an open access article distributed under the terms and conditions of the Creative Commons Attribution (CCBY) license (http://creativecommons.org/licenses/by/4.0/). 